\title{
Ocena wad i niezgodności spawalniczych metodą tomografii komputerowej CT
}

\author{
The assessment of defects and discontinuities \\ in weldings by means of computed tomography
}

\section{Streszczenie}

W artykule przedstawiono możliwość zastosowania badań metodą tomografii komputerowej CT do oceny struktury spawów. Metoda tomografii komputerowej w porównaniu do tradycyjnej radiografii daje dużo większe możliwości diagnozowania, kontroli złącz spawanych. Zwiększa się wykrywalność wad i niezgodności spawalniczych, co poprawia bezpieczeństwo eksploatacji. Metodą tomografii możemy dokładnie zwymiarować wadę we wszystkich jej kierunkach i zlokalizować przestrzennie w spoinie, co znacznie ułatwia diagnoście podjęcie ewentualnej decyzji o naprawie spawu lub całkowitym zbrakowaniu wyrobu. W artykule opisano także ograniczenia stosowania metody tomografii rentgenowskiej. Metoda ta jest szeroko wykorzystywana w przemyśle w procesie kontroli jakości produkcji jako metoda nieniszcząca NDT oraz w ramach profilaktycznych badań diagnostycznych.

Słowa kluczowe: kontrola NDT, wady i niezgodności spawalnicze, diagnozowanie, tomografia komputerowa

\section{Abstract}

In the paper a possibility of welding structure inspection by means of computed tomography was presented. In comparison to a traditional radiography, computed tomography method gives much more opportunities to diagnose and inspect welded joints. Thus it is easier to detect defects and discontinuities in weldings, what in turn increases safety of use. Tomography makes it possible to precisely attach to a defect dimensions in all directions and spatially localize it in a joint. This will help to take a decision regarding repair of the joint or consider a workpiece as a scrap. Limits of the use of computer tomography were also described. This solution is widely used in industry in production quality control process as a NDT method as well as in regular prevention diagnosis actions.

Keywords: NDT inspection, defects and discontinuities in welds, diagnosis, computed tomography

\section{Wstęp}

W procesie eksploatacji statków powietrznych występują różnego rodzaju uszkodzenia elementów jego konstrukcji, co skutkuje czasowym wycofaniem statku powietrznego z eksploatacji. Pociąga to za sobą konsekwencje finansowe związane zarówno z koniecznością jego usprawnienia, jak i przestojami w przypadku komercyjnych statków powietrznych. Najdalej idące konsekwencje mają uszkodzenia prowadzące do katastrof lotniczych, kiedy to poza zniszczeniem sprzętu mamy do czynienia z utratą życia wyszkolonej załogi oraz pasażerów.

Uszkodzenia techniki można zaliczyć do kilku grup przyczynowych, często ze sobą powiązanych. Do głównych przyczyn uszkodzeń zalicza się:

- wady produkcyjne,

- niewłaściwie przeprowadzony remont lub usprawnienie,

- błędy eksploatacyjne.

Odstępstwa od jakości produkcji i napraw to duża grupa uszkodzeń wykrywana w trakcie okresowych badań profilaktycznych techniki lotniczej prowadzonych zgodnie z systemem eksploatacji opracowanym dla danego typu obiektu. Uszkodzenia te, na które użytkownik nie ma wpływu i nie może im przeciwdziałać, mogą się ujawniać w całym okresie eksploatacji.

Zarówno podczas eksploatacji jak i produkcji oraz prowadzonych remontów istnieje możliwość dokładnej oceny stanu technicznego elementów przy pomocy wielu nieniszczących metod takich jak np. wizualna, penetracyjna, ultradźwiękowa czy radiograficzna (tradycyjna 2D) [1,2]. Metody te mają jednak ograniczoną zdolność oceny wad lub uszkodzeń wewnętrznych, pęknięć podpowierzchniowych, uszkodzeń występujących w materiałach wielowarstwowych. Często oceny takich wad dokonuje się dopiero podczas badań uszkodzonych elementów, kiedy uwidaczniają się one na powierzchni podczas diagnostyki wizualnej, a następnie weryfikuje się je wykonując badania metalograficzne [3].

Obecnie prowadzone są badania nad możliwością zasto-

Mgr inż. Artur Kułaszka, mgr inż. Marek Chalimoniuk - Instytut Techniczny Wojsk Lotniczych, prof. dr hab. inż. Michał Wieczorowski, mgr inż. Dariusz Brzozowski - ITA Sp. z o.o. Sp. k.

Autor korespondencyjny/Corresponding author. artur.kulaszka@itwl.pl 
sowania tomografii komputerowej CT do oceny struktury całego spektrum materiałów, takich jak stopy metaliczne, polimery, kompozyty oraz do oceny całych zespołów o złożonej budowie i skomplikowanej konstrukcji, a także badania betonów nawierzchniowych. Metoda ta jest szeroko wykorzystywana w przemyśle w procesie kontroli jakości produkcji jako metoda nieniszcząca NDT oraz w ramach profilaktycznych badań diagnostycznych.

Metoda tomografii komputerowej daje dużo dokładniejsze wyniki. Jako metoda nieniszcząca pozwala na weryfikację wad i uszkodzeń wewnątrz materiału.

\section{Metoda tomografii komputerowej (CT)}

Tomografia jest to zbiorcza nazwa metod diagnostycznych mających na celu uzyskanie przestrzennego obrazu przedstawiającego przekrój przez detal. Wyróżniamy kilka technik tomograficznych $[1,4,5]$ :

- "klasyczne" tomograficzne zdjęcie rentgenowskie;

- dwuwymiarowa ultrasonografia (USG 2D);

- tomografia komputerowa (CT, KT, TK);

- tomografia rezonansu magnetycznego (MRI, MR, NMR, MRT);

- pozytonowa tomografia emisyjna (PET);

- tomografia emisyjna pojedynczego fotonu (SPECT);

- koherentna tomografia optyczna (OCT).

W diagnostyce technicznej szerokie zastosowanie znalazła metoda tomografii komputerowej ang. Computed Tomography (CT). Jest rodzajem tomografii rentgenowskiej, pozwalającym na uzyskanie obrazów przestrzennych (3D) z prześwietlania badanego obiektu wykonanych z różnych kierunków. Urządzenie do CT nazywamy tomografem, a uzyskany obraz tomogramem (rys. 1.).
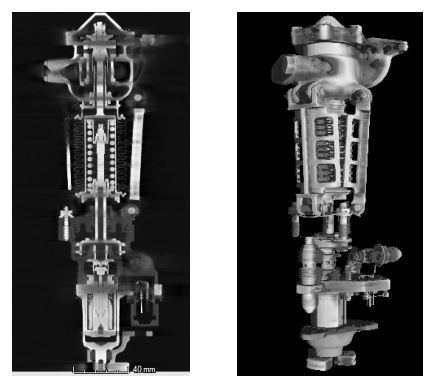

Rys. 1. Przykład tomogramu elementu o złożonej geometrii Fig. 1. An example of tomogram of a workpiece with complex geometry

Pierwszy tomograf zbudowała firma EMI Ltd z Wielkiej Brytanii w 1968 roku, a podstawy matematyczne opracował Johan Radon w 1917 roku [6].

Obecnie najczęściej stosowanymi metodami odtwarzania obrazu są metody analityczne. Dają one najlepsze wyniki, ale wymagają dużych mocy obliczeniowych. Metoda dwuwymiarowej analizy Fourierowskiej wykorzystuje szybką transformatę Fouriera do opisania otrzymanych profili pochłaniania. Transformacji poddaje się każdą z projekcji i dzięki temu uzyskuje się współczynnik pochłaniania w każdym z voxeli. Współczynniki pochłaniania zostają przeliczone na liczby $C T$, nazywane także jednostkami Hounsfielda HU [1] (1).

$$
1 H U=K \frac{\mu_{p}-\mu_{w}}{\mu_{w}}
$$

gdzie:

$K$ - stała wzmocnienia obrazu (indywidualna dla danego tomografu),

$\mu_{p}$ - współczynnik pochłaniania piksela,

$\mu_{w}$ - współczynnik pochłaniania wody (wartość odniesienia).
Zakres jednostek Hounsfielda dla CT wynosi od -1000 do +4000 .

Taki zakres pozwala na przedstawienie obrazu w odcieniach szarości. Ponieważ oko ludzkie jest w stanie rozróżnić tak szerokiego zakresu w praktyce stosuje się skalę 256 poziomów szarości. Stanowi to wybrany wycinek wartości liczby CT, pozwala jednak uzyskanie na ekranie monitora wysokiego kontrastu obrazu, co ułatwia jego interpretację.

Do diagnozowania elementów konstrukcji lotniczych niezbędna jest duża dokładność odwzorowania struktury wewnętrznej detalu w celu np. pomiarów geometrii, badań struktury materiału, wad, jak i do diagnozowania ich stanu $\mathrm{np}$. podczas naprawy (uszkodzenia termiczne, mikropęknięcia podpowierzchniowe i wewnątrz materiału rodzimego, zmiany struktury, zanieczyszczenia kanałów wewnętrznych itp.). W związku z powyższym najlepsze efekty uzyskuje się metodą z detektorem liniowym (rys. 2). W tej metodzie wiązka promieniowania jest ograniczana za pomocą przesłony do wiązki płaskiej i stosuje się cyfrowy detektor liniowy (jeden szereg czujników). Po wykonaniu obrotu przedmiotu o $360^{\circ}$ otrzymuje się płaski rentgenowski obraz plastra. W celu otrzymania obrazu przestrzennego całego detalu należy dodatkowo przesuwać detal w płaszczyźnie pionowej i za każdym krokiem wykonywać pełen obrót. Pełny obraz 3D uzyskuje się po przetworzeniu wszystkich zgromadzonych danych.

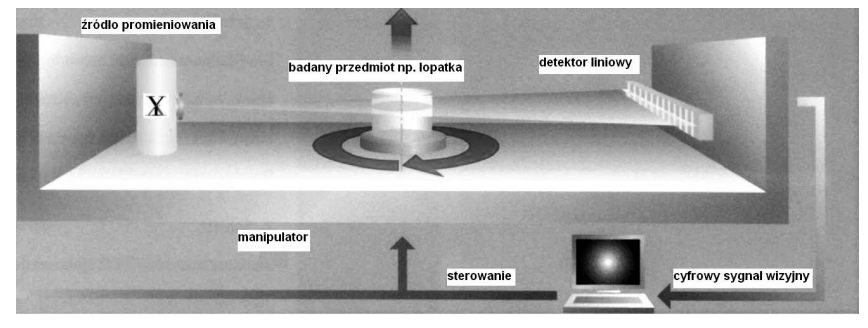

Rys. 2. Schemat badania tomograficznego $z$ detektorem liniowym [7] Fig. 2. A scheme of tomographic inspection with linear detector [7]

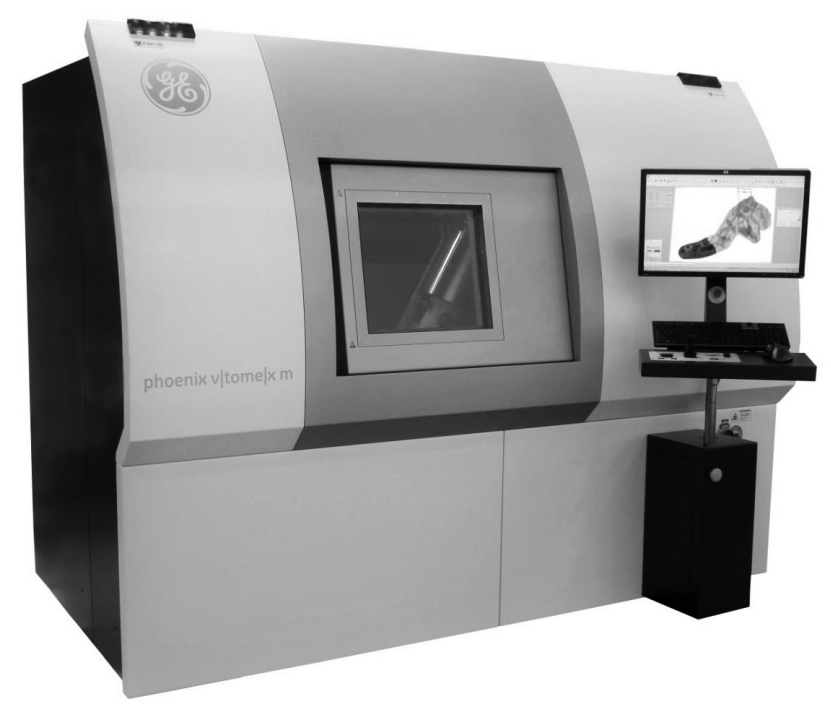

Rys. 3. Tomograf $z$ firmy GE V/Tome/x m Fig. 3. A GE V/Tome/x $m$ tomograph

Ze względu na dużą szybkość w badaniach radiografii cyfrowej coraz częściej wykorzystuje się detektory panelowe (wielokrotnie droższe od liniowych). W takim przypadku wiązka promieniowania jest kształtowana w stożek, a obraz otrzymuje się po wykonaniu jednego obrotu przedmiotu [8]. 
Takie rozwiązanie pozwala wielokrotnie zmniejszyć czas badania pojedynczego elementu z zachowaniem bardzo dobrej dokładności.

W 2012 roku Instytut Techniczny Wojsk Lotniczych zainstalował zakupiony od firmy ITA-Polska, przedstawiciela firmy GE Phoenix, tomograf typu v/tome/x m 300 (rys. 3) o max. mocy lampy $300 \mathrm{kV} / 500 \mathrm{~W}$. Ten nowoczesny tomograf umożliwia rozpoczęcie prac badawczych obejmujących szerokie spektrum materiałów lotniczych, np. stopy tytanu, stale, materiały kompozytowe, itp. Badania nieniszczące można prowadzić z bardzo dużą rozdzielczością. Wykrywane defekty poniżej 0,5 $\mu \mathrm{m}$ z wykorzystaniem lampy 180 kV lub materiałów o dużej gęstości, np. tytanowe łopatki lotnicze, wykorzystując lampę o mocy 300 kV. Masa badanych elementów do 50 kg, o wymiarach $500 \times 500 \times 600 \mathrm{~mm}$.

Tomografia komputerowa oprócz zastosowań lotniczych może być pomocna w badaniach w innych dziedzinach nauki, np. w badaniach lotniskowych nawierzchni betonowych, geologii, materiałów uzbrojenia, kompozytów i wielu innych. Na rysunkach $4 \div 7$ przedstawiono przykładowe obrazy uzyskane podczas badań różnych materiałów.

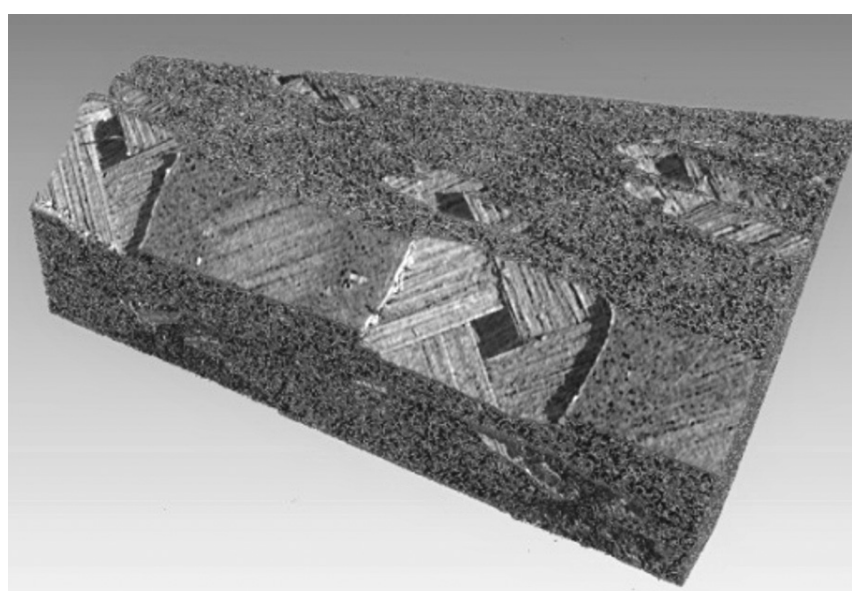

Rys. 4. Obraz materiału kompozytowego Fig. 4. An image of a composite material

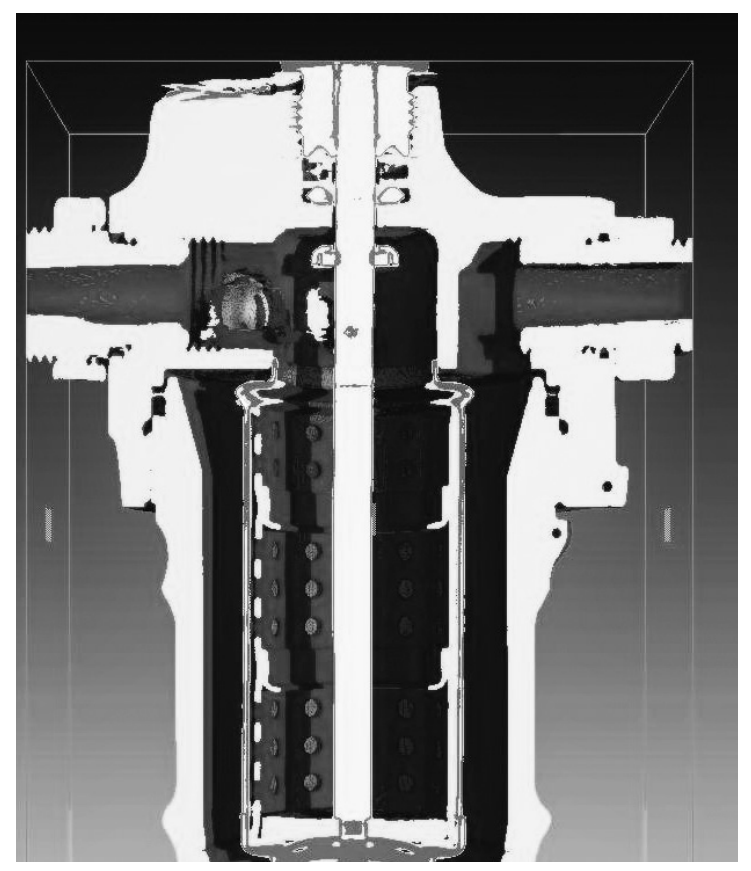

Rys. 5. Obraz filtra paliwa

Fig. 5. An image of a fuel filter

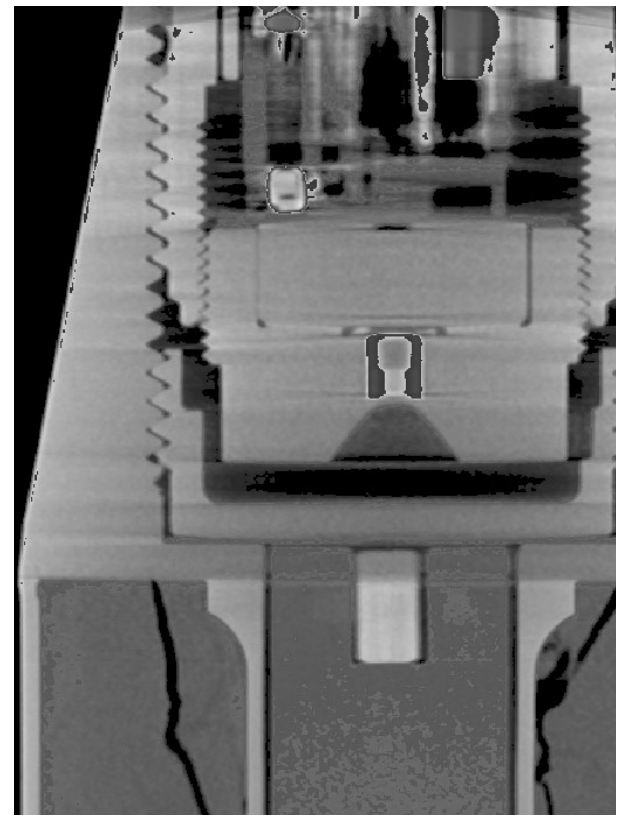

Rys. 6. Obraz głowicy bojowej

Fig. 6. An image of missile head

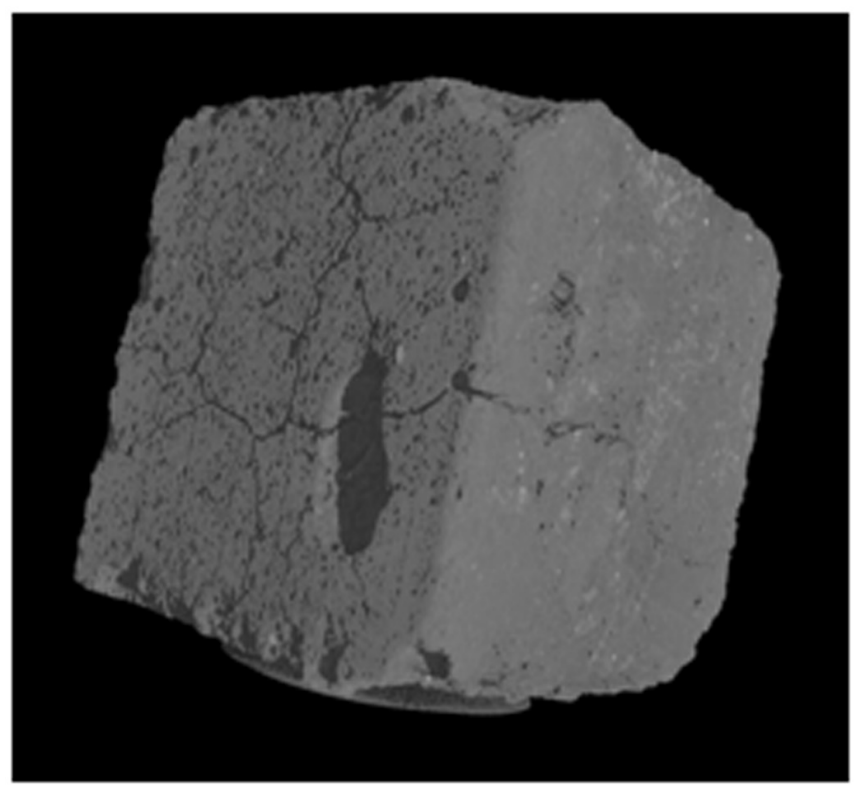

Rys. 7. Obraz betonu nawierzchniowego

Fig. 7. An image of concrete surface

Dzięki przejściu promieniowania przez cały obiekt tomografia rentgenowska pozwala na pomiary nawet bardzo złożonych obiektów z powierzchniami trudno dostępnymi oraz niewidocznymi wewnętrznymi inkluzjami i pustkami.

\section{Badanie spawów elementów konstrukcji lotniczych}

Produkcja lotnicza od zawsze związana jest z rygorystycznymi kryteriami oraz najwyższą jakością wytwarzania ze względu na to, iż każdy element statku powietrznego traktowany jest jako element krytyczny, mogący mieć wpływ na niezawodność i bezpieczeństwo całej konstrukcji lotniczej. Dlatego też każde nowe narzędzie diagnostyczne pozwalające szybciej, dokładniej, a co za tym idzie taniej skontrolować produkt jest chętnie i szybko wykorzystywany przez producentów. Taką metodą jest też tomografia komputerowa (CT) która znalazła zastosowanie między innymi do kontroli spawów elementów podwozia lotniczego. 
Badania prowadzone przez Instytut Techniczny Wojsk Lotniczych z wykorzystaniem tomografu typu v/tome/x m 300 firmy GE Phoenix wykazały przewagę tej metody badań nad dotychczas stosowaną metodą rentgenowską opartą na analizie błon radiograficznych. Obraz 3D pozyskany z tomografu jest o wiele dokładniejszy, przestrzenny, pozwalający na analizę badanego spawu w każdym kierunku i płaszczyźnie, rozróżnienie i wymiarowanie poszczególnych wad jeśli takowe wystę- pują. Skan obiektu zapisany w postaci pliku pozwala na jego późniejszą analizę z wykorzystaniem programu graficznego.

Metoda ta choć jest wspaniałym narzędziem dla diagnosty posiada także swoje ograniczenia. Do największych zaliczyć należy wysoki koszt zakupu, brak mobilności - zarówno te pracujące w układzie zamkniętym jak i otwartym oraz ograniczoną wielkością komory przestrzeń pomiarową (w zależności od modelu i typu).

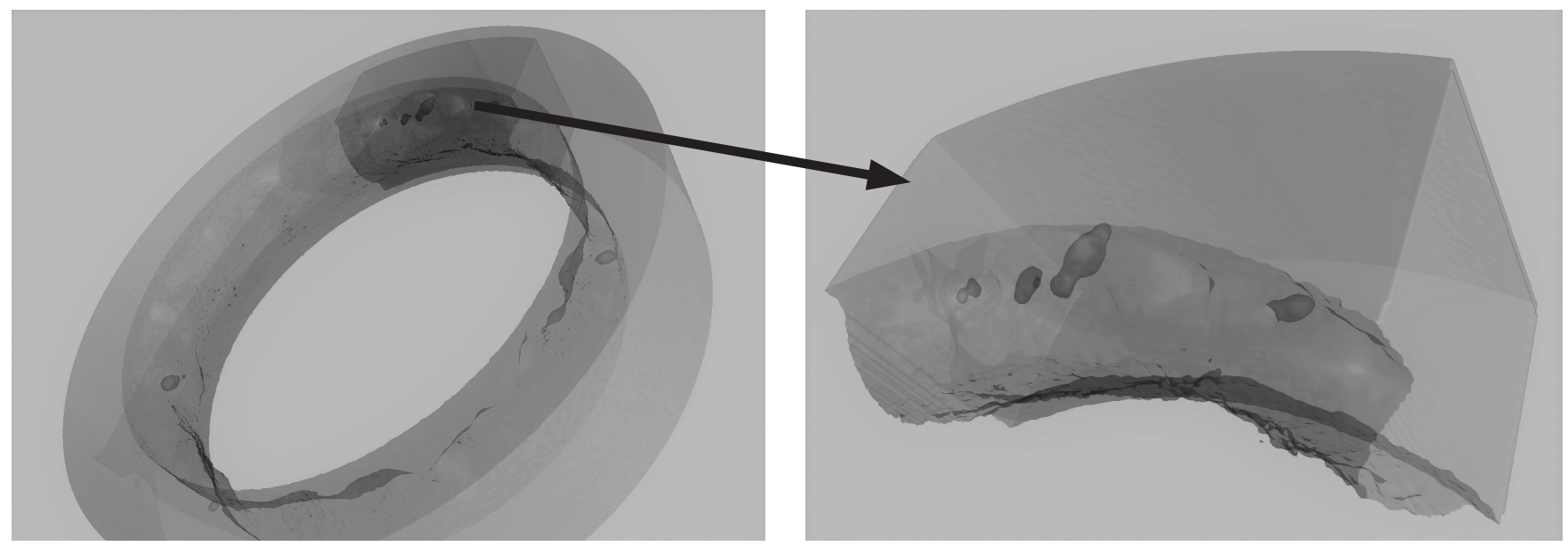

Rys. 8. Obraz spoiny 3D

Fig. 8. A 3D image of welded joints

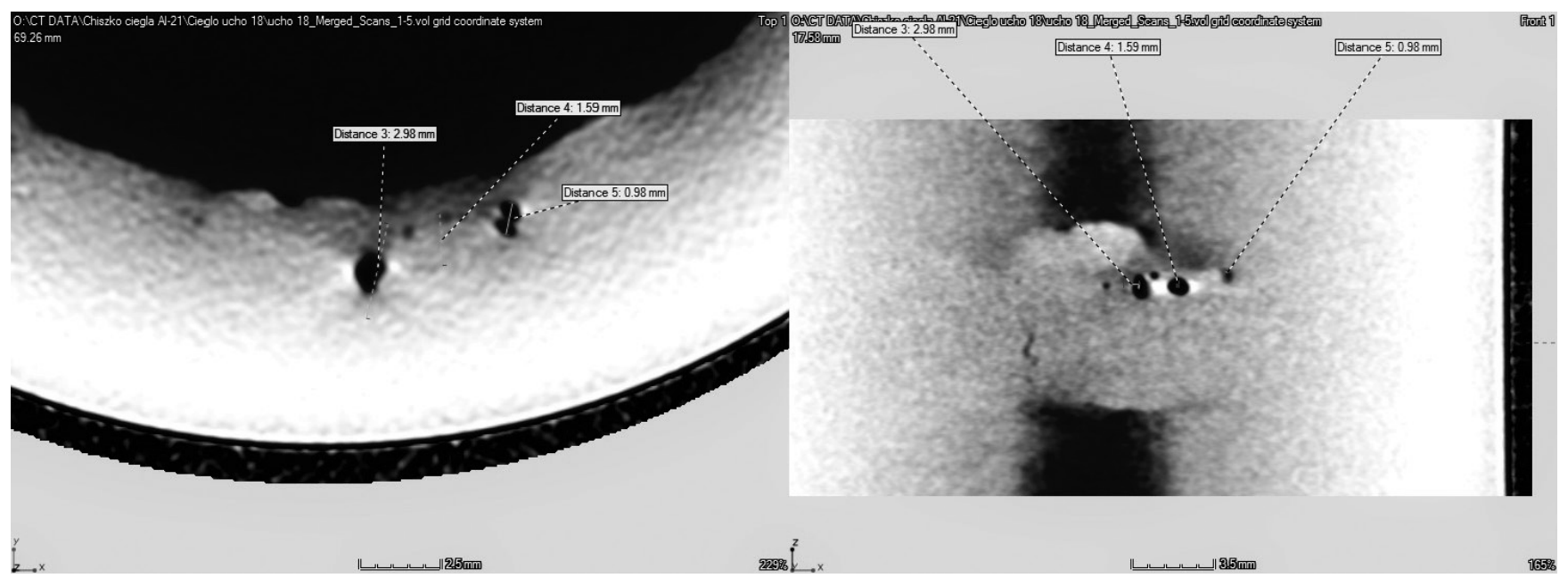

Rys. 9. Obraz spoiny $2 \mathrm{D}$

Fig. 9. A 2D image of welded joints

\section{Wnioski}

Proces weryfikacji konstrukcji lotniczych, zarówno na etapie produkcji jak i remontu jest bardzo istotną i odpowiedzialną operacją. Metoda tomografii komputerowej CT, pozwala w sposób bardziej wiarygodny, szybki i co najważniejsze nieniszczący dokonywać takiej weryfikacji (oceny). Z tego powodu metodę można stosować do sprawdzania $100 \%$ partii, nie tylko do reprezentatywnej próbki z danej partii. Zastosowanie tej metody w połączeniu z innymi metodami nieniszczącymi w znacznym stopniu podniesie prawdopodobieństwo wykrycia uszkodzenia elementów statków powietrznych.

\section{Literatura}

[1] J. Lewitowicz: Podstawy Eksploatacji Statków Powietrznych - Badania Eksploatacyjne Statków Powietrznych, T. 4., ITWL Warszawa 2007.

[2] S.W. Rumiancew: Radiologiczne metody defektoskopowe, Ośrodek Informacji o Energii Jądrowej, Warszawa 1970.

[3] J. Błachnio, A. Kułaszka: Computer aided visual inspection of the technical condition of gas turbine blades during their operation period. Journal of KONES Powertain and Transport, Vol. 16, No. 3, pp. 23-30, Warszawa, 2009.

[4] Materiały z zakładu Radiografii Centrum Onkologii w Bydgoszczy. Rentgenowska tomografia komputerowa. Bydgoszcz.
[5] Materiały z firmy Electronic Instrument Service: CT - Rentgenowska tomografia komputerowa w zastosowaniach przemysłowych.

[6] J. Błachnio, J. Pawlak: Damageability of gas turbine blades - evaluation of exhaust gas temperature in front of the turbine using a non-linear observer, w: Advances in Gas Turbine Technology, InTech, Warszawa 2011.

[7] R. Cierniak: Computed Tomography. Design principles of CT equipment. Algorithms for recovering of images. Warsaw 2005 (in Polish).

[8] M. Wieczorowski, B. Gapiński: X-ray CT in metrology of geometric feature, Acta Tehnica Corviniensis - Bulletin of Engineering, VII, 1, 95-100, 2014. 